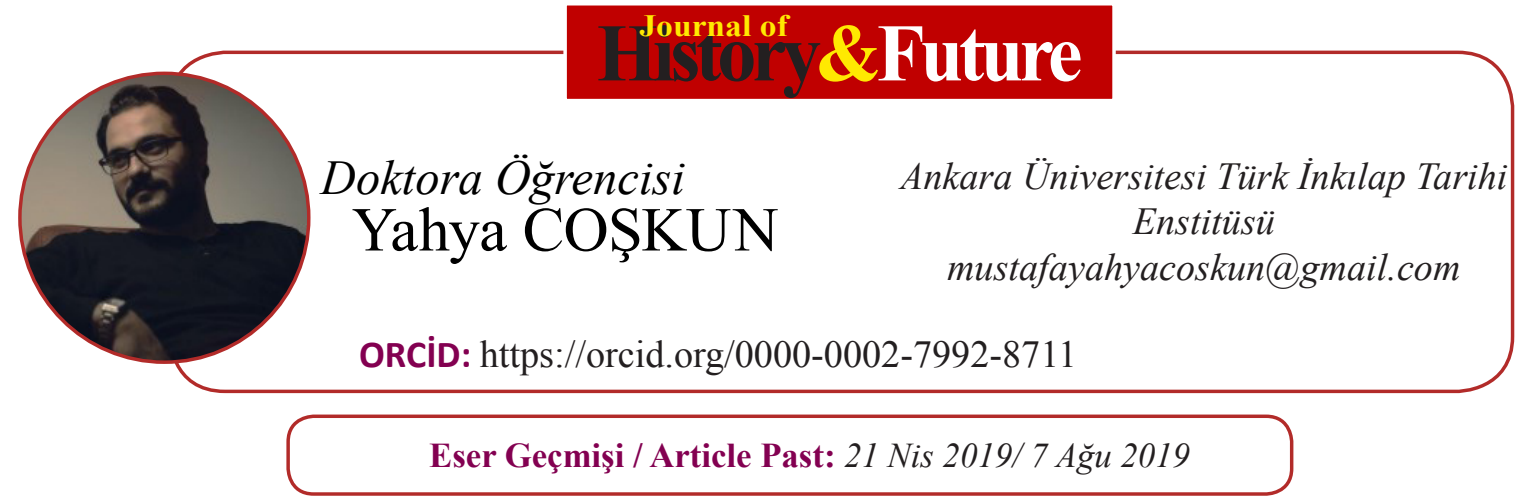

Araştırma Makalesi DOI: http://dx.doi.org/10.21551/jhf.556532 Research Paper

Orjinal Makale / Orginal Paper

\title{
Atatürk Dönemi Fikir Hareketleri
}

\section{Idea Movements in Atatürk Period}

\section{ÖZ}

Hem Osmanlı Devleti'nin son iki asrında hem de Türkiye Cumhuriyeti’nin kuruluş yıllarında fikir hareketleri, çoğunlukla dergiler etrafında şekillenmiştir. Bu dergiler, içerikleri ve iddiaları bakımından bağımsız olarak incelenmiş olmalarına rağmen özellikle Atatürk dönemindeki fikir hareketleri, bütüncül olarak ele alınıp bir tasnife tabi tutulmamıştır. Bu makalede dönemin belli başlı dergilerinden yola çıkılarak, Atatürk dönemi fikir hareketlerinin bir tasnifinin yapılması amaçlanmıştır. Bu tasnifle, asırlık kökleri olan fikir hareketlerinin, Osmanlı Devleti'nden Türkiye Cumhuriyeti'ne uzanan süreçte nasıl ve ne şekilde değiştiğinin anlaşılmasına katkı sağlanacağı düşünülmektedir.

Makalede Atatürk dönemi fikir hareketleri, üç başlikta ve üç devrede incelenmiştir. Birinci devre, 1920-1925 arasındaki klasik dönemdir. Bu dönemde Osmanlı'dan kalan fikir hareketleri, olduğu gibi varlığını sürdürmüştür. İkinci devre, 1925-1930 arasındaki istihale dönemidir. Bu dönemde başta Türkçülük olmak üzere fikir hareketleri bir istihale devresine girmiş, yeni dönemin kodlarına uygun bir hale gelecek şekilde değişmeye/dönüşmeye başlamıştır. Üçüncü devre ise 1930 sonrası Kemalizm dönemidir. Bu dönemde artık tek bir fikir hareketi kalmıştır, o da devrimin ideolojisi olan Kemalizm'dir. Ancak Atatürk'ün yaşadığı dönemde bile sınırları ve muhteviyatı belli tek bir Kemalizm anlayışı hâkim olmamıştır.

Anahtar Kelimeler: Atatürk, Fikir Hareketleri, Dergiler, İslamcılık, Türkçülük, Kemalizm

ATIF: COȘKUN Yahya, "Atatürk Dönemi Fikir Hareketleri” Tarih ve Gelecek Dergisi, 5/2

(Ağustos-2019), s. (344-359)

CITE: COŞKUN Yahya, "Idea Movements in Atatürk Perıd" Journal of History and Future, 5/2 : (August- 2019), pp. (344-359) 


\section{Abstract}

Idea movements had been shaped around journals in both last two centuries of Ottoman Empire and the founding years of Republic of Turkey. Although these journals were examined independently in terms of their contents and claims, the idea movements in the Ataturk period were not considered as holistic and classified. It is aimed in this article that to make a classification of the intellectual movements of Ataturk period based on the periodicals of the period. Through this classification, it is also aimed to clarify how these century-old idea movements have changed in the process extending from the Ottoman Empire to Republic of Turkey.

In this article, the idea movements of Atatürk period are examined under three titles and three cycles. The first period is the classical period between 1920 and 1925. During this period, the Ottoman intellectual movements remained as they were. The second period is the period of the invasion between 1925-1930. In this period, the intellectual movements, especially Turkism, entered into a period of tendering and began to change and transform in a way that made it compatible with the codes of the new era. The third and the last period is the period of Kemalism after 1930. There was only one idea movement in this period which was the ideology of the revolution, Kemalism. It is tried to be clarified that, however, even in the Ataturk era, there was not a single understanding of Kemalism that had certain limits and contents.

Keywords: Atatürk, Idea Movements, Journals, Islamism, Turkism, Kemalism

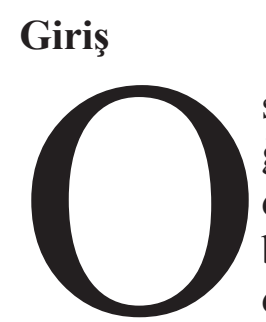

smanlı Devleti'nden Türkiye Cumhuriyeti'ne miras kalan fikir hareketleri, çoğunlukla dergiler etrafında şekillenmiştir. Osmanlı devrinde ve Cumhuriyet döneminde yayımlanan dergiler, hem içerik bakımından hem de iddiaları bakımından çoğunlukla incelenmiştir. Ancak özellikle Atatürk dönemindeki dergiler ve dergilerle şekillenen fikir hareketleri, bir tasnife tabi tutulmamıştır. $\mathrm{Bu}$ çalışma Atatürk devrindeki fikir hareketlerini, tasnif etmeyi amaçlamaktadır. Bu bağlamda 1920-1925 arasının Osmanlı' dan tevarüs edilen fikirlerin değişmeden yaşadığı klasik devre, 19251930 arasının, fikir hareketlerinin değişmeye ve başka bir hal almaya başladığı istihale devresi, 1930-1938 arasının ise tek fikir hareketi olarak Kemalizm Devresi olarak tasnifinin mümkün olacağı değerlendirilmektedir.

Osmanlı Devleti'nin son iki asrı bir değişme ve yenileşme tarihidir. Devletin gidişatından rahatsız olan yöneticiler, batının üstünlügüne karşı devletin askeri teşkilatını güçlendirerek orduda ve devlet idaresinde ilk reformları yaptılar. Bu reformlar zamanla bütün toplumu etkileyen zincirleme tepkilere yol açarak toplum hayatının her evresinde köklü değişmeleri zorunlu kıldı. ${ }^{1}$

Aslında Osmanlı modernleşmesinin, batılılaşmasının ve yenilik hareketlerinin tamamının başlangıç noktası, "Devleti nasıl kurtarabiliriz?" sorusu ve bu soruya aranan cevaptır.

Genç Osman'ın yeniçeriyi düzeltme arzusuyla başladığı ilk sslahat girişimlerinden 4. Murat'1n Koçi Bey’e hazırlattığı risalelere kadar uzatabileceğimiz yenileşme hareketleri, Tanzimat'la birlikte, o zamana dek yapılan tüm yenileşme hareketlerinden farklı olarak, devlet ve toplum düzeninin temellerini ve devlet işleyişini değiştirmeyi amaç edinmiştir. ${ }^{2}$

1 Kemal Karpat, Türk Demokrasi Tarihi, Timaş Yayınları, İstanbul 2010, s. 79

2 Fahir Armaoğlu, 19. Yüzyll Siyasi Tarihi (1789-1914), T.T.K., Ankara 1997, s. 222 
Devleti kurtarma teşebbüsleri, üç ana fikir etrafında şekillenmiştir. Osmanlıcılık ${ }^{3}$, İslamcılık ${ }^{4}$ ve Türkçülük ${ }^{5}$, üç ana fikir olarak belirginleşmiştir. ${ }^{6}$ Yine bu dönemde üç ana fikrin yanında, üç tali akım daha fikir hayatında kendisine yer bulmuştur. Bunlar, batıcılık ${ }^{7}$, teşebbüs-i şahsi ve adem-i merkeziyetçilik ${ }^{8}$ ile sosyalizm ${ }^{9}$ akımlarıdır. ${ }^{10}$ Bilhassa batıcılık daha sonra hatırı sayılır bir ilgi görecektir.

$\mathrm{Bu}$ fikir hareketlerinin büyük çoğunluğu, Cumhuriyet devrinde de varlıklarını sürdürmüştür. Osmanlı devrinde "Devleti kurtarma” çabalarına katkı sağlamaya çalışan akımlar, Cumhuriyet devrinde ise "Yeni devlete istikamet tayin edebilmek için" şekil veya kalıp değiştirerek etkili olmaya çalışmıştır.

3 Osmanlıcılık: 1789 Fransız İhtilâli sonrasında yayılan milliyetçilik akımlarının etkisiyle çağdaş anlamda millet tanımına giren halkların yaşadıkları topraklar üzerinde kendi devletlerini kurmak istemeleriyle ilgili faaliyetlerin önlenmesi amacıyla, devleti bir arada tutmak ve tüm unsurları Osmanlılık şemsiyesi altında toplamayı hedefleyen Osmanlı Devleti'nin ilk siyasî ideolojisidir. 2. Mahmut'un 1826'da söylediği, "Ben tebaamın Müslümanını camide, Hristiyan'ını kilisede, Musevi'sini havrada fark ederim, aralarında başka bir fark yoktur" cümlesi, Osmanlıcılık kavramının ana ilkesini oluşturur. Azmi Özcan, "Osmanlıc1lık", DIAA, İstanbul 2007, C. 33, s. 485-487

4 İslamcılık: Hıristiyan tebaanın Osmanlı ruhunu benimseyemeyeceğinin anlaşılması, dikkatlerin devlet içerisindeki Müslüman unsurlar üzerine çevrilmesine sebep olmuş, Osmanlı Devleti’nin bünyesindeki Müslümanları kaynaştırmak devlet politikası halini almıştır. Osmanlı Devleti’nde, Avrupa'da gelişen ve başarılı olan Pancermenizm ve Panslâvizm gibi ırka ve milliyete dayanan bir birlik meydana getirilemeyeceğini düşünen Sultan Abdülhamid tarafından etkili biçimde kullanılmaya çalışılmıştır. Salim Cöhçe, “XIX. Yüzyılın Sonlarında ve XX. Yüzyılın Başlarında Osmanlı Devleti’nde Fikir Hareketleri”, Erdem, Ocak 2000, C.12, sayı: 15, s. 340-343

5 Türkçülük: Başlangıçta siyasî bir mahiyet taşımayan ve tamamen kültür alanına yönelik bir karaktere sahip bulunan bu akım, Osmanlıcılık ve İslâmcılık politikalarının istenilen neticeleri vermemesi sonucunda çökmekte olan devletin enkazından Türk milletini kurtarmak maksadıyla doğmuştur. Salim Cöhçe, "XIX. Yüzyılın Sonlarında ve XX. Yüzyılın Başlarında Osmanlı Devleti’nde Fikir Hareketleri”, Erdem, s. 344-352

6 Yusuf Akçura, Üç Tarz-1 Siyaset, T.T.K., Ankara 1976, s. 19

7 Batıcılık: Kökleri 3. Selim döneminde uygulanmaya başlanan idarî reformlara kadar uzanan, batılı devletlerin başta askeri alan olmak üzere ilim ve tekniğinin Osmanlı Devleti’ne getirilmesini öngören daha sonraları yalnız bu sahada kalmayı siyasi ve sosyal hayatta da Avrupa usullerinin benimsenmesini öngören, bilhassa Tanzimat döneminde eğitim, hukuk gibi alanlarda batılı devletlerin tecrübelerinden istifade etmeyi amaçlayan akımdır. Salim Cöhçe, "XIX. Yüzyılın Sonlarında ve XX. Yüzyılın Başlarında Osmanlı Devleti’nde Fikir Hareketleri”, Erdem, s. 353-355

8 Teşebbüs-i Şahsi ve Adem-i Merkeziyetçilik: Prens Sabahattin tarafından Osmanlı toplumunun gelişet bilmesi için ferdiyetçi bir yapıya geçilmesi amacıyla devlet düzeninin yenilenmesi maksadıyla geliştirilmiş bir tekliftir. Yeni yetişecek burjuva sınıfının teşebbüsçülüğünü engellemeyecek bir yönetim biçiminin, ancak İngiliz ve Amerikan örneğine uygun bir adem-i merkeziyet modeli olabileceğine inanan Prens Sabahattin'e göre 1slahat bütün tebaayı kapsayacak, adem-i merkeziyet uygulanacak, seçimle gelecek belediye meclisi üyeleri mahallî idarede söz sahibi olacak, vilâyet meclislerinde azınlıklar, nüfusları oranında temsil edilecek, Osmanlı tebaası arasında imtiyazlı hiçbir grup bulunmayacaktır. Jandarma teşkilâtında her azınlık, nüfusu oranında yer alacak, yalnız vali, mutasarrıf, defterdar, mahkeme reisleri merkezî idare tarafından tayin edilecekti. Şerif Mardin, "Adem-i Merkeziyet", DİA, İstanbul 1988, C.1, s. 364-367

9 Sosyalizm: Sosyalizm (Fr. socialisme), özel mülkiyetin ve gelir dağılımının, fertlerin sadece kendi menfaatlerini korumaları suretiyle veya kapitalizm şartlarında piyasa güçlerinin serbest işleyişi yoluyla belirlenmeyip toplumun denetimine bağl1 tutulduğu toplumsal örgütlenme sistemine ve ideolojisine verilen addır. Hilal Görgün, "Sosyalizm”, DIA, İstanbul 2009, C. 37, S. 382-388

10 Fuat Uçar, "Türk Düşüncesinde Osmanlıcılık Fikrinin Ortaya Çıkışı ve Türk Siyasal Hayatına Etkileri”, Karadeniz Sosyal Bilimler Dergisi, Haziran 2018, C. 10, s. 85-86 
Devlet politikası olduğundan hareketle Osmanlıcılık akımını ${ }^{11}$ hariç tutarsak, diğer tüm fikir hareketleri ya dergiler etrafında şekillenmiş yahut da seslerini duyurabilmek için bir dergi etrafında toplanmışlardır. Düşünce akımlarının hemen hepsi, aydınlara da halka da dergilerle ulaşmaya çalıştırılmıştır. ${ }^{12}$

Osmanlı döneminde başlayan bu gelenek, Cumhuriyet devrinde de devam etmiş, fikir hareketleri, dergiler etrafında şekillenmeyi sürdürmüştür. Bu sebeple hem Osmanlı Devleti'nin son iki asrındaki hem de Atatürk dönemindeki fikir hareketlerine mercek tutabilmek için en çok, dönemin dergilerine bakmak gerekmektedir.

\section{Dergiler}

\section{İslamcı Dergiler}

2. Abdülhamit' in tahttan indirilmesi ve İttihat Terakki yönetiminin iktidarıyla birlikte etkinliğini kaybetmeye başlayan İslamcılık fikrinin ana temsilcisi, 1908 yılında Sırât-1 Müstakîm adıyla yayın hayatına başlayan ${ }^{13}$ ve sonradan ismi değişen Sebilürreşad Mecmuası'dır.

Sebilürreşad, milli mücadele döneminde, İtilaf Devletlerine ve saraya karşı cephe almış, "Bugün, icma-i ümmet Anadolu'dadır" serlevhasıyla Kuva-yı Milliye’yi desteklemiştir. Mecmuanın kurucularından Eşref Edip ve yazarlarından Mehmet Akif, Mustafa Kemal Paşa tarafindan Ankara'ya davet edilmiş, Sebilürreşad, Ankara'da basılmaya başlanmış ve Milli Hükümet tarafından binlerce bastırılarak bütün cephelere dağıtılmıştır. ${ }^{14}$ Ancak 1924 yılından başlayarak Sebilürreşad Mecmuası, başta İslami meseleler olmak üzere Türkiye Cumhuriyeti'nin izlediği yeni yolu eleştirmeye, hükümetin icraatlarını tenkit etmeye başlamıştır. Her ne kadar özenli bir dil kullanmaya gayret etse de 1925 yılında Takrir-i Sükûn ${ }^{15}$ yasasıyla kapatılmıştır. ${ }^{16}$

Yine Millî Mücadele günlerinin heyecan dolu havası içinde yayın hayatına giren ve büyük ölçüde Yahya Kemal'in görüşleri doğrultusunda çıkan bir diğer dergi ise Dergâh'tır. Millî Mücadele'yi destekleyen Dergâh, adından da anlaşılacağı üzere, mistik yönü ağır basan bir dergidir. Hem İslamcı hem de Türkçü dergiler içerisinde anılabilecek Dergâh, tarih ve kültüre dayalı yeni bir milliyetçilik anlayışının sesi olmuştur. ${ }^{17}$

Dergâh Dergisi'nin içinden doğan, 1923 Kasım'ında çıkmaya başlayıp 1925 yılında yayın hayatına son veren diğer bir dergi, Mihrap'tır. Mihrap, başlı̆̆ı altındaki “içtimaî, ahlâkî, felsefî, tarihî, edebî” ibaresine rağmen felsefe ve sosyoloji ağırlıklı bir dergidir. ${ }^{18}$ Bununla birlikte dergi,

11 Şerif Demir, 'Tanzimat Döneminde Bir Devlet Politikası Olarak Osmanlıcılık', Türkiyat Araştırmaları Dergisi, S. 29, 2011, s. 331- 348

12 Mustafa Oral, Kemalist Cumhuriyet’in İşası Bir İdeolojik Aygıt Olarak Ülkü Mecmuası, Yeni İnsan Yayınevi, İstanbul, Mayıs 2016, s. 25

13 Adem Efe, "Sebilürreşad”, DİA, İstanbul 2009, C. 36, s. 251

14 Eşref Edip, İstiklal Mahkemelerinde-Sebilürreşad'ın Romanı-, Hz. Fahrettin Gün, Beyan Yay., 2. Baskı, İstanbul 2005, s.17

15 Takrir-i Sükûn: Şeyh Sait önderliğindeki isyanın bastırılması için 4 Mart 1925’te, hükümete geniş yetkiler veren kanundur. Bu yasa, devrimlerin önünü açmak ve devrim karşıtı yayın yapan basını susturmak için de kullanılmıştır. Ömer Mete, Anılarda Takrir-i Sükûn Dönemi Uygulamaları (19rq_ 19ro), Ankara Üniversitesi, Türk İnkılâp Tarihi Enstitüsü, Yayımlanmamış Yüksek Lisans Tezi, Ankara 2014

16 Eşref Edip, Millî Mücadele Yıllarl, Hz. Fahrettin Gün, Beyan Yay., İstanbul 2011, s. 15

17 Abdullah Uçman, "Dergâh”, DİA, İstanbul 1994, C. 9, s. 172-173

18 Erdoğan Erbay, "Mihrap”, DIA İstanbul 2005, C. 30, s. 29-30 
günün meselelerine de değinmiş, sözünü tüm taraflara söylemeye, sesini herkese duyurmaya çabalamış ve oldukça özenli bir biçimde iktidara yol göstermeye de çalışmıştır.

Mehmet Emin Bey'in, Mihrap dergisinde yayınlanan ilk musahabesi, ikinci sayıda yer alan “Terakki Etrafında Birleşemez miyiz?" başlığını taşımaktadır. Yazar, bu makalesinde, fikirleri çarpıştırmak yerine bir hedefe yönelerek ilerlemek gerektiğinden bahsetmiştir. Diğer bir yazısında "Ben ne liberaller gibi medreseler kapansın ne de muhafazakârlar gibi medreseler aynı şekilde kalsın diyorum. Benim kanaatimce medreselere iyi bir inkılap yapılmalı ve medreseler, assın şartlarına uygun hale getirilmelidir" diyerek fikirlerini beyan etmiştir. ${ }^{19}$

Derginin yazarlarından Abdülhak Hadi Bey ise günün başka bir tartışma konusunu yorumlamış, Fransız kanunlarını alıp uygulayalım diyen Garpçıları haksız bulduğunu, bir İslam memleketinde bu kanunlarının tatbikinin kolay olmayacağını, şeriatla çelişen kanunların olacağını belirtmiştir. Şarkçıları da eleştiren yazar, onlardan da dünyada meydana gelen siyasi, iktisadî ve ilmî değişikliklerin farkına varmalarını istemiştir. ${ }^{20}$

Takrir-i Sükûn'la kapatılan Sebilürreşad'dan sonra uzun bir süre, İslamcılık iddiasında olan bir dergi yayımlanmamıştır.

\section{Marksist- Sosyalist Dergiler}

1920’li yılların ilk yarısında güçlenen diğer bir fikir hareketi, diyalektik materyalizmdir. 1. Meşrutiyet yıllarında ilk belirtileri görülen 2. Meşrutiyet döneminde biraz daha belirginleşen sosyalizm ve sosyal demokrasi hareketleri, mütarekeyle birlikte hız kazanmıştır. "Sosyalizmden bahseder ilim ve sanat mecmuası" Kurtuluş, Eylül 1919'da yayımlanmaya başlamıştır. 1920 Şubat'ına kadar beş sayı çıkmıştır. Kurtuluş,a göre Türkiye'nin gündeminde ekonomik gelişme vardır. Ekonomik gelişmeyle birlikte sol düşünce de güçlenecektir. ${ }^{21}$

İlk sayısı Haziran 1921 'de yayınlanan Aydınlık, solda radikal tavır koyan bir dergi olmuştur. Entelektüel derinliğe sahip dergilerden Aydınlık, dört yıla yakın bir zaman Türkiye'de Marksizm'in bilimsel temelleri atan en önemli dergilerden olmuştur. ${ }^{22}$ Aydınlık ve Orak Çekiç de Takrir-i Sükûn'la kapatılmıştır. ${ }^{23}$ 2. Meşrutiyet devrinde başlayan sosyalist yayınların da Takrir-i Sükûn'la sesi kısılmıştır.

\section{3- Türkçü Dergiler}

Türkçülük akımının ilk dergilerinden biri olan ve ideolojinin yayın organı kabul edilen Genç Kalemler, Hüsn ve Şiir'in devamı olarak 1910 yılının sonlarında çıkmaya başlamıştır. Dergiye esas şeklini verenler Ziya Gökalp ve Ömer Seyfettin olmuştur. Dergi, İttihat ve Terakki'den, maddi/ manevi destek görmüştür. Türkçenin sadeleştirilmesini savunmuşlardır. Derginin edebiyattaki yeri kadar siyasetteki yeri de çok önemlidir. Yeni yeni filizlenen Türkçülük akımının zemini, ideolojik

19 Ayşe Tepebaşı, Mihrab, Şen Yuva, Çă̆layan, Meşale, Çığır Dergilerinin Değerlendirilmesi, Tahlili ve Fihristi, Gaziosman Paşa Üniversitesi, Sosyal Bilimler Enstitüsü, Yayımlanmamış Yüksek Lisans Tezi, Tokat 2011, s. 94

21 Zafer Toprak, Türkiye' de Dergiler Ansiklopediler, Gelişim, İstanbul 1984, s. $28-29$

22 Zafer Toprak, “Aydınlık Dergisi [1921-1925], Marksizm ve Feminizm,” Müteferrika, sayı 50, Kış 2016/2, s. 3-6.

23 Suzan Ünal, 1923 ve 1927 Seçimleri, Dora, Bursa 2016, s. 208 
alt yapısı, bu derginin sayfalarında şekillenmeye başlamıştır. ${ }^{24}$

24 Kasım 1911 tarihinde on beş günlük periyotlarla çıkarılmaya başlanan ve 1917'den itibaren Türk Ocaklarının resmi yayın organı haline gelen Türk Yurdu Mecmuası da Türkçülük hareketini savunan en uzun ömürlü dergi olmuştur. ${ }^{25}$

Uzun ömürlü olması, neredeyse her sosyal ve siyasi olaya değinmesi ve yazar kadrosunun çok kuvvetli kalemlerden oluşması, Türk Yurdu'nu sadece Türkçülük akımı içerisinde değil Osmanlı Devleti ve Türkiye Cumhuriyeti'nin tüm fikir hareketleri içerisinde çok önemli bir mevkie taş1maktadır. Türk Yurdu, ayrıca Cumhuriyet'e olan entelektüel katkılarından dolayı da çok önemlidir. ${ }^{26} \mathrm{Bu}$ dergi ve savunduğu fikirler de yine şekil ve biçim değiştirerek varlığını sürdürebilmiştir.

\section{0-1925: Fikirde Klasik Devre}

Millî mücadele döneminde İslam, milliyetçilik ve sosyalizm iç içe geçmiş biçimde kendine yer bulmuş ve ilginç bir şekilde birbirine karışmıştır. ${ }^{27}$ Bu sebeple fikri hayattaki varlıklarını da sürdürmüşlerdir. Yukarda zikredilen Sebilürreşad, Dergah, Mihrap, Kurtuluş, Aydınlık, Orak Çekiç, Genç Kalemler ve Türk Yurdu gibi mecmular, 1920-1925 yılları arasında iddialarını, Osmanlı Devleti'ndeki gibi sürdürmüşlerdir.

Ancak 1923-1925 yılları arasında Cumhuriyet'in temel ilkeler yavaş yavaş belirginleşmeye başlamıştır. Bunlar, milliyetçilik, halkçılık ve laikliktir. Laiklik ve halkçılık zaman içerisinde açık ifadelerine kavuşacak, ${ }^{28}$ milliyetçilik ise Turancılıktan uzaklaşıp Anadolu milliyetçiliğine ve zamanla Atatürk milliyetçiliğine doğru dönüşecektir.

İslamcı ve sosyalist akımların görünürlükleri, Takrir-i Sükûn'la birlikte azalmaya başlamış, neredeyse kaybolmaya yüz tutmuştur. Milliyetçilik ise istihalelerle varlığını sürdürmüştür. ${ }^{29}$

\section{5-1930: İstihale Devresi}

Takrir-i Sükûn, Türkiye Cumhuriyeti tarihinde bir kırılma noktası olmuştur. Örgütlü muhalefet ortadan kaldırılmış, muhalif basın susturulmuş, hükümet tüm kudretiyle iş görebilecek hale gelmiştir. ${ }^{30}$ Her türlü muhalefeti yasaklayan bu kanunun etkisiyle yeni Cumhuriyet, arzu ettiği radikal dönüşümleri de gerçekleştirecek ortamı yakalamıştır. ${ }^{31}$ Nitekim kanunun yürürlükte olduğu dört yılda, kılık-kıyafetten alfabeye kadar sosyal hayatı yeniden tanzim eden köklü reformlar yapilmıştır.

Sosyal ve siyasi hayatın köklü değişimlere uğradığg bu dönemde fikri hayatta da tabii olarak değişimler meydana gelmiştir. Artık iki asırdır dillere pelesenk olan ve sürekli umut kaynağı olan

24 Hüseyin Çelik, "Genç Kalemler”, DİA, İstanbul 1996, C. 14, s. 21-23

25 Hüseyin Tuncer, «Türk Yurdu”, TDV İslâm Ansiklopedisi, https://islamansiklopedisi.org.tr/turk-yurdu I.G.T., (04.12.2018).

26 Mustafa Gündüz, 2. Meşrutiyet' in Klasik Paradigmalarl, Lotus, Ankara 2007, s. 361

27 Taner Timur, Türk Devrimi ve Sonrası, İmge Kitabevi, 8. Baskı, Ankara 2018, s.37

28 Kemal Karpat, Türk Demokrasi Tarihi, Timaş Yayınları, İstanbul 2010, s. 135

29 Milliyetçiliğin dönüşümü hakkında Bkz. Çağla Gül Yesevi, "Türk Milliyetçiliğinin Evrimi”, Sosyal ve Beşeri Bilimler Dergisi, C. 4, No:2, 2012, s. 75-85

30 Kemal Karpat, Türk Demokrasi Tarihi, Timaş Yayınları, İstanbul 2010, s. 135

31 Temuçin Faik Ertan, Kadrocular ve Kadro Hareketi, T.C. Kültür Bakanlığı Yayınları, Ankara, 1994, s.9 
fikirler, yerini yeni arayışlara bırakmıştır. Kimi aydınlar gerçekten yeni bir şey söylemeye çalışmış kimileri ise gittikçe ağırlaşan ve muhalif seslere pek de yaşama imkânı tanımayan siyasi hava yüzünden aykırı sesler çıkarmamayı tercih etmiştir. ${ }^{32}$

$\mathrm{Bu}$ devre, köklü ve keskin fikir akımlarının değil genç Cumhuriyetin sorunlarının konuşulduğu devredir. Uluslaşmanın, Türk devriminin muhteviyat ve sınırlarının müeddep bir dille konuşulduğu bu devrede Milli Mecmua ${ }^{33}$, Hayat ${ }^{34}$ gibi dergiler yayın hayatında görünür hale gelmiştir.

Yayın hayatının başlarında Türk Ocaklarının faaliyetlerine geniş yer veren hatta Yeni Mecmua'nın kopyası olarak İttihatçılıkla itham edilen Milli Mecmua, zamanla inkılapların ayrı ayrı ele alınıp savunulduğu bir mecraya dönmüştür..$^{35}$

Ahmet Cevat Emre'nin 1928'de çıkarmaya başladığı Muhit Dergisi, Kemalizm kavramının ilk kez kullanıldığı ve sistematik biçimde ele alındığ 1 dergi olmuştur. ${ }^{36}$

Artık bu dönemde yalnızca dergiler değil dergileri çıkaran kurum ve müesseseler de zamanla aynı dönüşüme uğramaya başlamış ve yavaş yavaş Türk İnkılabının ideolojisinin oluşturulmaya başlandığı döneme geçilmiştir.

Siyasi sahada tek parti iktidarının gücü eline aldığı, sosyal alanda inkılabın ideolojisini oluşturma çabalarının başladığı bu dönemde, Türk Ocakları da 1927 yılındaki 4. Kurultayında "Cumhuriyet Halk Firkası ile devlet siyasetinde beraber" olduğunu açıklamış, daha sonra CHF Nizamnamesinde yer alan 40. Maddeyle CHF'nin murakabesi altında bir kuruluş sayılmıştır. ${ }^{37}$

Bundan sonra devrimlerin yaygınlaştırılması, gençlerin devrim aydınlığında yetiştirilmesi gibi çalışmalar, Türk Ocaklarının öncelikli görevleri arasına girmiştir. Hazırlanan raporlarda bu yolda ne kadar mesafe kat edildiği kayıt altına alınmıştır. Örneğin, Türk Ocakları 1929 yılının ilk üç ayında yaklaşık 50.000 kişinin yeni harfleri öğrenmesini sağlamıştır. ${ }^{38}$

32 Takrir-i Sükûn Kanunu'na dayanılarak kapatılan gazeteler, Hüseyin Cahid'in bir daha siyasi yazı yazmayacağına dair açıklaması, gazetecilerin yargılanması, bazı gazetecilerin yeniden gazete çıkarmalarına ve yazı yazmalarına müsaade edilmediği gibi hususlar için Bkz. Sezen Kılıç, "Cumhuriyetin İlk Yıllarındaki Gelişmeleri Basının Yorumlayışı (1923-1926)”, Atatürk Araştırma Merkezi Dergisi, C. 24, Say1: 70, 2008, s. 149-194

33 Yahya Saim (Ozanoğlu) tarafından Milli Mecmua’nın 1. sayısında kaleme alınan başyazıda Türk Yurdu, Yeni Mecmua gibi dergilerle açılan yolun, muzaffer Anadolu’yu doğurduğuna işaret edilmiş, Millî Mecmua'nın hedefi ise medenî milletlerin yolundan yürüyerek mefkûreci gençliğin ifadesi olmaya çalışmak olarak nitelendirilmiştir. Alim Kahraman, "Milli Mecmua”, DİA, İstanbul 2005, C. 30 s. 75

34 Hayat, Cumhuriyet'in ilânından üç yıl sonra yayına başlamış, 2 Aralık 1926'dan 30 Aralık 1929'a kadar çıkmıştır. Yayımlandığı üç yıl boyunca bilhassa Cumhuriyet inkılâplarının ve Cumhuriyet rejiminin dayandığı fikrî ve kültürel temellerin oluşturulmasında ve bunların benimsenmesinde önemli bir rol oynamış, dergideki yazılar hep bu çerçeve içinde yazılmıştır. Abdullah Uçman, "Hayat”, DİA, İstanbul 1988, C.17, s. $12-14$

36 Lemi Atalay, Atatürk Dönemi Düşünürlerinin Gözüyle Kemalizm ve Türk Inkılabı, Ankara Üniversitesi Türk İnkılap Tarihi Enstitüsü, Yayımlanmamış Yüksek Lisans Tezi, Ankara 2004, s. 38

37 Füsun Üstel, Türk Ocakları, İletişim Yay., 3. Bsk., İstanbul 2010, s. 227

38 Füsun Üstel, Türk Ocaklarl, s. 328 


\section{Yeni Dönem: 1930 ve Kemalizm}

1930 yılı, Türkiye için hem ekonomik hem de sosyal alandaki kırılmalarla yeni dönemin başladığ̣ yıl olmuştur. İzmir iktisat kongresinden beri devam eden teşebbüs hürriyeti öncelikli iktisat politikası, 1929 buhranının oluşturduğu ekonomik hava ile yerini devlet müdahaleciliği öncelikli kalkınmaya bırakmıştır. Serbest Cumhuriyet Fırka tecrübesi ve hemen ardından patlak veren Menemen hadisesi ${ }^{39}$, devrimlerin toplumun tüm kesimleri tarafından kabullenilmediğini göstermiş, devrimin halka anlatılmasının bir mecburiyet olduğunu teyit etmiş ve devrimin ideolojisinin oluşturulması çalışmalarına başlanmıştır. ${ }^{40}$

1930’lu yıllar, rejimin tehlikede olduğuna inanılan ve bunu önlemek için önlemlerin alınmaya çalışıldığı, ekonomik kalkınmanın öncelikli olduğu, "bir devrim ideolojisi” üretilmesi çabaları ile inkılabın halka benimsetilmesi için propaganda faaliyetlerinin arttığ 1 , bir dönem olmuştur. ${ }^{41}$

Bu dönemde Türk Ocakları kapatılmış, yerine Halkevleri açılmış, Halkevleri ve İstanbul Üniversitesi eliyle Cumhuriyet'in yeni vatandaş tipi biçimlendirilmeye başlanmıştır. Ulus-devlet inşası için tarih ve dil çalışmalarına başlanmış, yeni ideolojinin alt yapısını oluşturmak üzere Türk Tarih Kurumu ile Türk Dil Kurumu kurulmuştur. Kemalizm’in içinin doldurulabilmesi için yeni yayınlar çıkarılmış, ders kitapları tanzim edilmiş, aydınlardan da bu yönde çalışmalar beklenmiştir. Hatta parti içerisinde ideoloji oluşturma işlevinin öncülüğünü yapan parti Genel Sekreteri Recep Peker, bu girişimleri ilk başlarda teşvik de etmiştir. ${ }^{42}$ Nitekim aydınlar da bu işe gönüllü olmuştur. Artık iki asırlık fikirlerin yerini yeni ve neredeyse tek bir fikir akımı almıştır, o da Kemalizm'dir.

Kemalizm, pratiği ideolojisinden önde giden bir tecrübe olduğu için ideoloji/fikir hareketi oluştururken yapılanlara, uygulamalara uygun bir alt zemin oluşturulmaya çalışılmıştır. Ancak burada esas dikkat edilmesi gereken husus, aydınların, bu yeni girişimlere müktesebatlarıyla dâhil oldukları gerçeğidir. Yani herkes Kemalizm'i, kendi penceresinden yorumlamaya çalışmış, Kemalizm'in içini kendi müktesebatıyla doldurmaya çalışmıştır. Bu sebeple Şevket Süreyya'nın Kemalizm'i ile Tekinalp'in Kemalizm'i yahut da Ahmet Hamdi Başar'1n Kemalizm'i ile Hüseyin Cahit'in Kemalizm'i birbirlerinden farklılık arz etmiştir.

\section{Yeni Dönemin Yayınları}

\section{1- Halkevleri ve Ülkü}

Halkçılık, öteden beri Atatürk'ün üstünde durduğu en önemli kavramlardan biri olmuştur. Mustafa Kemal Paşa, Türkiye'de, Batı'da olduğu gibi çıkarları birbiriyle çatışan sınıfların bulun-

\footnotetext{
3923 Aralık 1930 tarihinde İzmir'in Menemen ilçesinde, Derviş Mehmet adlı bir kişinin kendisini Mehdi ilan ettiği, etrafına topladığı kişilerle şeriat istediği ve olayları bastırmak üzere gelen yedek subay Kubilay'ın başının kesilerek katledilmesiyle neticelenen ayaklanma. Necdet Aysal, "Yönetsel Alanda Değişimler ve Devrim Hareketlerine Karşı Gerici Tepkiler "Serbest Cumhuriyet Fırkası -Menemen Olayı", Ankara Üniversitesi Türk İnkılâp Tarihi Enstitüsü Atatürk Yolu Dergisi, Sayı, 44, Güz 2009, s. 581-625

40 Temuçin Faik Ertan, Atatürk Döneminde Devletçilik-Liberalizm Tartışmaları, Phoenix, Ankara 2010, s. $12-13$

41 Hakan Uzun, “Tek Parti Döneminde Yapılan Cumhuriyet Halk Partisi Kongreleri Temelinde Değişmez Genel Başkanlık, Kemalizm ve Milli Şef Kavramları”, Dokuz Eylül Üniversitesi Çağdas, Türkiye Tarihi Araştırmaları Dergisi, Cilt IX, Sayı, 20-21, 2010 Bahar-Güz, s. 239

42 Hakan Uzun, "Tek Parti Döneminde Yapılan Cumhuriyet Halk Partisi Kongreleri Temelinde Değişmez Genel Başkanlık, Kemalizm ve Milli Şef Kavramları”, s.247
} 
madığını, imtiyazsız, sınıfsız bir kitle olarak mesleklere ayrılmış bir halkın olduğunu savunmuştur. ${ }^{43}$ Nitekim 24 Nisan 1920'de, hükümet kurulması amacıyla TBMM Başkanlığına sunduğu önergede, Halk hükümeti tabirini kullanmıştır. ${ }^{44}$

Halkevleri, tarihten spora, lisandan güzel sanatlara uzanan geniş çalışma kollarıyla toplumun tüm kesimine hitap eden birer kültür merkezi haline gelmiştir. 1933 yılında da ismini bizzat Atatürk'ün verdiği Ülkü̈ ${ }^{45}$, Halkevleri merkez yayın organı olarak yayın hayatına başlamıştır. ${ }^{46}$

Derginin ilk sayısındaki "Ülkü Niçin Çıkıyor” adlı makale, derginin yayın hayatına başlamasını gayet coşkulu bir dille açıklamıştır. Dergi, "karanlık devirleri arkada bırakarak şerefli ve aydınlık bir istikbale giden yeni neslin heyecanını beslemek için" ${ }^{47}$ çıkmıştır.

Ülkü, yalnızca ideolojik bir araç olarak kalmamış, devrin önemli kalemlerinin eserlerinin yayımlandığı bir mecra olmayı da başarmıştır. Ahmet Hamdi'nin Beş Şehir denemesi ile Mahur Beste romanları ilk kez Ülkü'de tefrika edilmiş, Niyazi Berkes'in “Amerika Birleşik Devletleri'nde Sosyoloji”, yazısı bu dergide yayımlanmıştır. ${ }^{48}$

Ülkü’nün, arkasındaki güce rağmen istenileni veremediği yönünde eleştirildiği de olmuştur. Hıfzı Oğuz Bekata'nın çıkardığı Çığır Mecmuasında, Ülkü, 1000 sayfalık birinci yılında, bir iki yazı hariç, Türk inkılabına dair yeni bir şey söyleyememesi, muayyen meselelerde de sistemli bir tahlil yapamaması iddialarıyla eleştirilmiştir. ${ }^{49}$

Yakup Kadri de anılarında Ülkü’yü, uzun yıllar dolgun tahsisatla yayımlanan, hiç kimsenin okumadığ 1 ve belki de görmediği bir fikir dergisi olarak nitelemiştir. ${ }^{50}$

\section{2- Çı̆̆ır}

Hıfzı Oğuz Bekata'nın yayımladığı Çığır, Ocak 1933'de yayın hayatına başlamış ve kendisini 'Gençlik Dergisi' olarak tanıtmıştır. Dergi, 1948 yılına dek 193 sayı çıkmıştır. ${ }^{51}$ Antikomünist, milliyetçi bir isim olan Hıfzı Oğuz’un çıkardığ 1 dergi de devrin diğer yayın organlarından farklı değildir. Çığır'ın sayfaları, inkılap neslinin gençlerine hedefler gösteren meşaleler gibidir. Çığır'ın sayfalarında devrimi anlatmak için yapılması gereken birçok teklif olmakla beraber o günlerde belki yeteri kadar konuşulmayan sinemanın da dergide kendine yer bulması ayrıca önemli olarak değerlendirilebilir. Hıfzı Oğuz, inkılap sineması istemektedir. Yapılan filmlerde inkılap gençliğinin unutulduğundan şikâyet etmektedir. Devrimin gücünün beyaz perdede somutlaşmasını iste-

43 Taner Timur, Türk Devrimi ve Sonrasl, s. 118

44 Mustafa Oral, Kemalist Cumhuriyet'in İnşası Bir İdeolojik Aygıt Olarak Ülkü Mecmuasl, s. 79

45 Mustafa Oral, Kemalist Cumhuriyet'in İnşası Bir İdeolojik Aygıt Olarak Ülkü Mecmuası adlı kitabının 14. sayfasında, derginin çıkış tarihini 19 Şubat 1932 olarak vermiştir.

İbrahim Erdal, "Ülkü Mecmuasına Göre Erken Cumhuriyet Dönemi Nüfus Politikası (1923-1938)”, Ankara Üniversitesi Türk İnkılâp Tarihi Enstitüsü Atatürk Yolu Dergisi, S. 48, Güz 2011, s. 780

Recep (Peker), “Ülkü Niçin Çıkıyor”, Ülkü Mecmuası, 1933, Cilt:1, Sayı:1, s:1-2

48 Mustafa Oral, Kemalist Cumhuriyet'in İnşası Bir İdeolojik Aygıt Olarak Ülkü Mecmuası, s. 130-131

49 Mustafa Oral, Kemalist Cumhuriyet'in Inşası Bir İdeolojik Aygıt Olarak Ülkü Mecmuası, s. 128-129

50 Bkz. Yakup Kadri Karaosmanoğlu, Zoraki Diplomat, İletişim Yayınları ve Yakup Kadri Karaosmanoğlu, Politikada 45 Yll, İletişim Yayınları

51 H. Aliyar Demirci, Çı̆̆ır Dergisi ve Hıfzı Oğuz Bekata, Ankara Üniversitesi, Sosyal Bilimler Enstitüsü, Kamu Yönetimi ve Siyaset Bilimi Ana Bilim Dalı, Yayımlanmamış Yüksek Lisans Tezi, Ankara 1995, s.9 
mektedir. $^{52}$

\section{3- Kadro}

Kadro Dergisi, Türk inkılabına bir doktrin oluşturmak üzere 23 Ocak 1932'de yayımlanmıştır. Kadro düşüncesinin temeli, Şevket Süreyya'nın Ocak 1931'de Türk Ocakları Genel Merkezi'nde verdiği “Kadro ve İkılap”, başlıklı konferanstır. ${ }^{53}$

Kadro, ilk sayısında niçin çıktığını okuyucularına açık bir biçimde duyurmuştur. Kadro, inkılabın “kendine has cihanı telakki tarzının” vücut bulması için çıkmıştır. ${ }^{54}$ Kadro, inkılabın ideolojisini yapma iddiasindadir.

Yakup Kadri, Kadro’yu niçin çıkardıklarını anlatırken, Halk Partili mebusların bile devletçilikten bihaber olduklarını, mebuslara ve halka, Halk Partisi'nin ilkelerini anlatmak için bir dergi çıkartmak istediğini ifade etmiştir..$^{55}$

Kadrocular, devletçiliği, planlı kalkınmayı ve sınıfsız-ayrıcalıklı toplum yaratılmasını savunmuşlardır. ${ }^{56}$ Kadrocular, halkın ileri kısmını temsil eden bir grubun, yani aydın ve öncü bir kadronun, yani devrimleri gerçekleştiren kadronun topluma önderlik etmesi ile sorunların kolay yoldan aşılacağını ifade etmişlerdir. ${ }^{57}$

Kadro, müstemleke iktisadından milli iktisada giden yolu kapitalist ve Marksist ekonominin dışında bir üçüncü yol olarak nitelemiş ve devletçiliği, devletin yalnız ekonomiye değil tüm sosyal hayata egemen olması biçiminde okumuştur.

Kadro'nun, kurtarıcı ve öncü kadroya inancı o kadar kuvvetlidir ki, Türk devriminin idarede ve partide ikiliği kabul edemeyeceği dile getirilmiş, hatta parlamentarizmin, siyasetin ve siyasi partilerin gereksiz olduğu da ifade edilmiştir. Kadronun teklifinin, Sovyetler'deki Komünist Partiden, İtalya'daki Faşist Partiden, Almanya'daki Nasyonal Sosyalist İşçi Partisinden farkı olmadığı söylenince, onlardakilerin sınıf diktatörlüğü teşkilatı olduğunu hâlbuki kendi önerilerinin milli rehberlik formülü oluğunu dile getirmişlerdir..$^{58}$

Gerçekte Kadro'nun felsefesi, Marksizm'in milliyetçilik ve korporatizmin yüzeysel bir karması gibi görünmektedir. ${ }^{59}$

İnkılabın ideolojisini yapma görevini gönüllü olarak üstlenen Kadro’ya, parti içinden de tepkiler gelmiştir. Başta Recep Peker ve çevresi, ideoloji oluşturma işinin partiye ait olduğunu iddia emiştir. Ayrıca sermayenin önemli temsilcisi sayılan İş Bankası'nın önde gelenleri, liberal-demokrat aydınlar da Kadrocuları eleştirmiştir. ${ }^{60} \mathrm{Bu}$ bağlamda bilhassa Ağaoğlu Ahmet ile Hüseyin Cahit'in eleştirileri oldukça sıkı ve şiddetli tenkitler olarak değerlendirilebilir.

\footnotetext{
52 H. Aliyar Demirci, Çığır Dergisi ve Hıfzı Oğuz Bekata, Yayımlanmamış Yüksek Lisans Tezi, s. 23

53 Halit Erdem Oksaçan, "Kadro” Dergisi ve İktisadi Devletçilik, Agora Kitaplı̆̆ , İstanbul 2016, s. 111

54 Kadro, Say1 1, İkincikanun 1932, s. 3

55 Temuçin Faik Ertan, “Kadro Dergisi Niçin Kapandı?”, Atatürk Dergisi Journal of Atatürk, Cilt: III, Say1: 4, Temmuz 2003, s. 19-34.

56 Temuçin Faik Ertan, Atatürk Döneminde Devletçilik-Liberalizm Tartışmaları, s. 39

57 Kemal KARPAT, Türk Demokrasi Tarihi, Timaş Yayınları, İstanbul 2010, s. 156-157

58 Halit Erdem Oksaçan, "Kadro” Dergisi ve İktisadi Devletçilik, s.192

59 Kemal Karpat, Türk Demokrasi Tarihi, İstanbul 2010, s. 156-157

60 Temuçin Faik Ertan, Atatürk Döneminde Devletçilik-Liberalizm Tartışmaları, s. 40
} 


\section{4- Fikir Hareketleri}

30'lu yıllar, totaliter rejimlerin dünyaya hâkim olduğu yıllardır ve Hüseyin Cahit, hem yazıları hem de çevirileriyle bu tehlikeye, müeddep bir dille dikkat çekmeye çalışmıştır. Antidemokratik akımların olumsuz taraflarını belirginleştirmiş, demokrasinin ve siyasi liberalizmin önemini vurgulamaya çalışmıştır. Bilhassa Kadro ve Kooperatif dergileriyle girdiği polemiklerde bu hususların altını sürekli çizmiştir. ${ }^{61}$

Hüseyin Cahit, İttihatçıların yayın organı olan Tanin'i çıkaran eski devrin önemli simalarındandır. İttihatçı bir gazetecidir. ${ }^{62}$ Hüseyin Cahit, Cumhuriyet'in onuncu yıldönümünde Fikir Hareketleri adlı dergisini çıkarmaya başlamıştır. Liberal düşüncenin, bireyciliğin ve demokrasinin savunuculuğunu yapmıştır. Hüseyin Cahit, Cumhuriyet'in ilk yıllarında iktidarla ters düşmüştür. Yargılanması, ceza almas1, onun tek partili siyasi rejimi daha iyi algılamasına sebep olmuştur. ${ }^{63}$

Hüseyin Cahit'in devrim yönetimi tarafından hoş görülmeyen yaklaşımlarının olması, bu derginin kişisel bir meşruiyet kazanma çabasının sonucu olduğuna ilişkin çözümlemeleri gündeme getirmiştir. ${ }^{64}$ Ancak 364 sayı çıkan bir derginin sadece kendini müdafaa için çıkarılmış olması yeterli bir açıklama olmamalıdır. Bununla birlikte Hüseyin Cahit'in, ismi üstündeki bulutları dağıtmaya çalıştığı, kendisine yöneltilen suçlamalara cevap verdiği de muhakkaktır.

Hüseyin Cahit, dergisindeki yazılarıyla, iktidarla uzlaşmaya çabalamış, Atatürk'ün ölümünden sonra uzlaşma, yakınlaşmaya dönmüş ve neticelenmiştir. Nihayet Hüseyin Cahit, 1939 yılında Çankırı milletvekili olarak sisteme dâhil olmuştur. ${ }^{65}$

Hüseyin Cahit, Kadrocuların, inkılabın ideolojisini yapma iddialarını en sert dille eleştirenlerden biridir. Kadrocuların, “Kendilerini inkılap namına söz söyleme salahiyetini haiz” sanmalarından başlayarak "Türk inkılabını milli hâkimiyet prensibinden ayırarak faşistliğe yahut devlet sosyalistliğine götürmeye” çalıştıklarını dile getirmiştir. Ona göre Türk inkılabı objektif bir hakikattir, inkılabın fikrî ve siyasî abideleri meydandadır. ${ }^{66}$

\section{5- Kooperatif}

1923 yılında yapılan İzmir İktisat Kongresinin delegelerinden olan, İstanbul Ticaret ve Sanayi Odasının millileştirilmesinde büyük rolü bulunan Ahmet Hamdi Başar'ın fikrî hayata yeni katkıları, Mustafa Kemal Paşa'nın 1930 yılında çıktığı büyük seyahatte Atatürk’e müşavirlik yapmasıyla

\footnotetext{
61 Lemi Atalay, Atatürk Dönemi Düşünürlerinin Gözüyle Kemalizm ve Türk İnkılabl, Ankara Üniversitesi Türk İnkılap Tarihi Enstitüsü, Yayımlanmamış Yüksek Lisans Tezi, Ankara 2004, s. 45

62 Temuçin Faik Ertan, Atatürk Döneminde Devletçilik-Liberalizm Tartışmaları, s.20

63 Temuçin Faik Ertan, Atatürk Döneminde Devletçilik-Liberalizm Tartışmaları, s. 45

64 Ali Haydar Fırat, Bir Dönem Tartışmalarının Seyri: 1932-1935 Yıllarında Matbuat Tartışmaları Bağlamında Kadro, Kooperatif ve Fikir Hareketleri Dergileri, Ankara Üniversitesi Sosyal Bilimler Enstitüsü Gazetecilik Anabilim Dalı, Yayımlanmamış Yüksek Lisans Tezi, Ankara 2005, s. 86

65 Hilmi Bengi, Gazeteci, Siyasetçi ve Fikir Adamı Olarak Hüseyin Cahit Yalçın, Atatürk Araştırma Merkezi Yayınları, Ankara 2000, s. 268-275

66 Hüseyin Cahit, Fikir Hareketleri, Sayı 37, 5 Temmuz 1934
} 
başlamıştır. Başar, Atatürk için orijinal teklifler hazırlamıştır. Ona göre Türkiye ne sosyalist ne de kapitalist ekonomi içinde kalkınabilirdi. Başar, iktisadın uzmanlarca yönetilmesini, devletin iktisada tahakküm etmeden hür teşebbüsün önünü açması gerektiğini, "kapı kulu” sisteminin değişmesi gerektiğini düşünüyordu. Ancak Ahmet Hamdi Bey, Gazi’nin etrafını saran zümreler yüzünden raporlarını sunamamıştır. ${ }^{67}$ Başar, bunun üzerine fikirlerini kitap, dergi ve konferanslarla duyurmaya çalışmıştır. ${ }^{68}$ Kooperatif Dergisini de bu sebeple 1932 yılında çıkarmıştır.

Kooperatif de daha ilk sayısında çıkış amacını, "Cumhuriyet Devrimine birtakım katkılar sunma” olarak ilan etmiştir.

Devletçilik olgusu Ahmet Hamdi'de dönemsel bir yaklaşımı ifade eder. Bu yaklaşım, devletin bütün alanlarda egemen olmasını değil zorunlu toplumsal ihtiyaçların karşılanmasını ve devletin ekonomi alanında alt-yapı çalışmalarını gerçekleştirmesini ve sonrasında bu alandan çekilmesini öngörmektedir. Dolayısıyla devletin bürokratik niteliğinin ve egemenliğinin genişlemesine karşıdır. Çünkü bu tür bir yapılanmanın yeni bir sınıf ortaya çıkaracağı düşüncesindedir ve bu fikrini şöyle özetlemiştir: "Müteşebbis ve kapitalist" yerine bir "memur" sınıfının genişlemesini isteyen "devletçilik" ile "iktisadi devletçilik" arasında fark vardır. ${ }^{69}$

\section{6- Kültür Haftası}

Osmanlı Devleti'nin son devrinde ve Türkiye Cumhuriyeti'nin ilk dönemlerinde yayımlanan birçok dergi ve gazetede yazılar yazan, çalışkan bir entelektüel olan Ağaoğlu Ahmet, Serbest Fırka tecrübesinden sonra kalemi oldukça keskinleşen isimlerden biridir. Zaten daha evvel de fikirlerini açıkça söylemekten imtina etmediği için birkaç kez okları üzerine çekmeyi başarmış muhtelif devirlerde iktidarın gözünden düşmüştür. ${ }^{70}$

1936 yılının Ocak ve Haziran ayları arasında 21 sayı çıkan Kültür Haftası'nın hamisi Ağaoğlu Ahmet'tir. Bu dergi, ilk sayısında sıkı bir kültür sorgulamasıyla yayın hayatına başlamış ve bir nevi kültürel bildiri yayımlamıştır. Akın ${ }^{71}$ gibi keskin olmayan Kültür Haftası, gerçekten kültürü öncelemiş, önemli yazarların fikir ve düşünce yazılarına ağırlık vermiştir. Örneğin Peyami Safa’nın daha sonra "Türk İnkılabına Bakışlar" adıyla kitaplaşacak yazılarının bir kısmı da bu dergide yayımlanmiştır. ${ }^{72}$

Dergi, ilk sayısından itibaren döneminin birçok ünlü simasını bir araya getirmiştir. Şiirleriyle Ahmet Hamdi Tanpınar, Faruk Nafiz Çamlıbel ve Cahit Sıtkı Tarancı'nın bulunduğu ilk sayıdaki diğer imzalar şunlardır: Mustafa Şekip Tunç, Ahmet Ağaoğlu, Suut Kemal Yetkin, Mesut Cemil Tel, Peyami Safa, Elif Naci, Nizamettin Nazif Tepedelenlioğlu. Peyami Safa, ikinci sayıdaki yazısında, edebiyatın her şeyden önce millî bir estetik çerçeve içinde kabul edilmesi lâzım gelen

67 Başar’ın tekliflerini sunduğunu ancak bu tekliflerin kabul görmediğini söyleyenler de vardır.

68 Hilmi Ziya Ülken, Türkiye’ de Çăgdaş Düşünce Tarihi, Ülken Yay., 2. Bsk, İstanbul 1979, s. $465-469$

69 Ali Haydar Fırat, Bir Dönem Tartışmalarının Seyri: 1932-1935 Yıllarında Matbuat Tartışmaları Bağlamında Kadro, Kooperatif ve Fikir Hareketleri Dergileri, Ankara Üniversitesi Sosyal Bilimler Enstitüsü Gazetecilik Anabilim Dalı, Yayımlanmamış Yüksek Lisans Tezi, Ankara 2005, s. 123

70 Ahmet Ağaoğlu, Serbest Fırka Hatıraları, İletişim, İstanbul 2011, s. 35-36

71 Akın: Serbest Fırka Tecrübesi sonrasında belki de asla sisteme geri dönemeyeceğini bildiği için bu dönemde iktidarın gözüne girmeye çalışmadan yazan ender isimlerden olan Ahmet Ağaoğlu'nun, 1933 yılında çıkarttığı, ancak altı ayını bile doldurmadan hükûmet eleştirileri yüzünden kapatılan gazetesidir. 
bir mefhum olduğunu, edebiyatta memleket manzarasını silerek yerine sınırsız bir yabancılık aşkı doldurmamak gerektiğini ifade etmiştir. ${ }^{73}$

\section{7- Yeni Adam}

Osmanlı devrinde yüksek memuriyetlerde bulunmuş ve İkdam başta olmak üzere önemli gazetelerde yazılar yazmış olan İsmail Hakkı (Baltacığlu) yeni iktidarla anlaşamamış ve 1933 yılında "kadro dışı" kalmış isimlerden biridir. İsmail Hakkı, sistemin dışına itilmekten dolayı pek muzdarip olmuştur. Geçinmek için yeni bir dergi kurmuş ve bu dergide inkılabı yeni nesillere duyurma işine girmiştir. 1 Ocak 1934 tarihinde yayın hayatına başlayan Yeni Adam'ın alt başlığg, derginin muhteviyatını ve istikametini göstermektedir: "Ülkümüz, Demokrasi ve Cumhuriyet İçin Çalışmaktır" İktidarla kavga ettikten sonra iktidarın sesi olarak yorumlanabilecek bir dergi çıkaran İsmail Hakkı'nın bu çabası, siteme eklemlenmek ümidiyle dergi çıkartmak olarak yorumlanmıştır. ${ }^{74}$

\section{Sonuç}

Genel hatlarıyla üç döneme ayırabileceğimiz Atatürk dönemi fikir hareketlerinin ilk dönemi, 1920-1925 yılları arasında Osmanlı'dan tevarüs edilen İslamcılık, Türkçülük, Batıcılık ve Sosyalizm'den oluşan klasik devredir. İkinci dönem, 1925-1930 yılları arasında Takrir-i Sükun'la klasik akımların sesinin kesildiği ve Türkçülüğün bir dönüşüm devresine girip şekil değiştirmeye başladığı istihale devresidir. Üçüncü dönem ise inkılabın ideolojisinin oluşturulmaya çalışıldığ yalnızca bir tek fikir akımının kaldığı Kemalist devredir. Bu dönemde altı çizilmesi gereken husus ise Kemalizm'in içini doldurmaya çalışan herkesin bu yeni ideolojiyi kendi müktesebatıyla yorumlamaya çalıştığı ve aslında örtülü olarak Kemalizm’i kendi fikirleriyle tekemmül ettirmeye çalıştı̆̆ıdır.

1930 sonrası yeni dönemde her ne kadar bazı dergiler arasında sıkı polemikler yaşanmış, bazı yazarlar arasında söz düelloları gerçekleşmiş olsa da kimse açıktan yeni dönem aleyhinde pek bir şey söylememiştir. Söz düelloları, Kemalizm'in içinin nasıl doldurulacağıyla alakalı olmuş, bizzat Kemalizm'le yahut da yönetim biçimiyle alakalı kayda değer tenkitler yapılmamıştır. 1935 yılına kadar genel hatları tam anlamıla belirlenemeyen Kemalizm, parti programının netleşmesinden sonra ihtilafları biraz daha azalmış, benzerlikleri biraz daha artmış olarak resmi görüşe uygun bir biçim almıştır. Ancak 1930'lu yıllarda başlayan “Kemalizm’in ne olduğu meselesi” bugün bile canlılığını koruyarak tartışılmaya devam etmektedir. Bugün de birbirinden çok faklı görüşleri bulunan, demokrat, liberal, otoriter eğilimlerle birbirlerinden farklı şekilde açıklanmaya çalışılan Kemalizm algılayışlarının bulunduğu bir gerçektir. Öncelikli düsturunun çağdaşlaşma olması, çağ yakalamak için yeniliklere açık kalması, pratiğinin teorisinden önce gelmesi ve "donup kalmaması" için içeriğinin netleştirilmemesi gibi özellikleri, Kemalizm'in, bugün bile farklı farklı kabullerle ele alınmasına sebebiyet vermiştir.

1930'lu yıllarda Kemalizm ile ilgili polemiklere bakarken Peyami Safa'nın Türk inkılabına Bakışlar adlı kitabının ikinci baskısı için yazdığı önsözdeki cümleyi hep hatırda tutmak gerekir. “'Bu kitap 1938'de yazıldı ve Cumhuriyet gazetesinde tefrika şeklinde yayınland1. Atatürk'ün son günleriydi. O devre mahsus yazı disiplini, eserin Kemalizm’e, altı oka, tarih ve dil anlayışına ait

\footnotetext{
73 Beşir Ayvazoğlu, "Kültür Haftası”, DİA, İstanbul 2002, C. 26, s. 546-547

74 Mehmet Güngör, "Çağın Önünde Bir Aydın: İsmayıl Hakkı Baltacığlu”, Mersin Üniversitesi Eğitim Fakültesi Dergisi, Cilt 4, Sayı 1, Haziran 2008, s.62-63
} 
son fasıllarında resmi teze uymak zoruyla, muharririn düşünce hürriyetinden bazı kısıntılara katlanmasinı zaruri k1liyordu." ${ }^{75}$

\section{Kaynakça}

Kitap ve Makaleler

AĞAOĞLU, Ahmet, Serbest Fırka Hatıraları, İletişim, İstanbul 2011

AKÇURA, Yusuf, Üç Tarz-ı Siyaset, T.T.K., Ankara 1976

AYSAL, Necdet, "Yönetsel Alanda Değişimler ve Devrim Hareketlerine Karşı Gerici Tepkiler "Serbest Cumhuriyet Fırkası -Menemen Olayı", Ankara Üniversitesi Türk Inkılâp Tarihi Enstitüsü Atatürk Yolu Dergisi, Say1, 44, Güz 2009, s. 581-625

AYVAZOĞLU, Beşir, “Kültür Haftası”, DİA, İstanbul 2002, C. 26, s. 546-547

ARMAOĞLU, Fahir, 19. Yüzyıl Siyasi Tarihi (1789-1914), T.T.K., Ankara 1997

BENGİ, Hilmi, Gazeteci, Siyasetçi ve Fikir Adamı Olarak Hüseyin Cahit Yalçın, Atatürk Araştırma Merkezi Yayınları, Ankara 2000

CÖHÇE, Salim, “XIX. Yüzyılın Sonlarında ve XX. Yüzyılın Başlarında Osmanlı Devleti’nde Fikir Hareketleri”, Erdem, Ocak 2000, C.12, say1: 15, s. 340-343

ÇELIKK, Hüseyin, “Genç Kalemler”, DİA, İstanbul 1996, C. 14

DEMIR, Şerif, ' 'Tanzimat Döneminde Bir Devlet Politikası Olarak Osmanlıcılık', Türkiyat Araştırmaları Dergisi, S. 29, 2011, s. 331- 348

EFE, Adem, “Sebilürreşad”, $D \dot{I} A$, İstanbul 2009, C. 36, s. 251

EDİP, Eşref, İstiklal Mahkemelerinde- Sebilürreşad'ın Romant-, Hz. Fahrettin Gün, Beyan Yay., 2. Bask1, İstanbul 2005,

EDİP, Eşref, Milli Mücadele Yılları, Hz. Fahrettin Gün, Beyan Yay., İstanbul 2011

ERDAL, İbrahim, "Ülkü Mecmuasına Göre Erken Cumhuriyet Dönemi Nüfus Politikası (1923-1938)”, Ankara Üniversitesi Türk Inkılâp Tarihi Enstitüsü Atatürk Yolu Dergisi S. 48, Güz 2011

ERBAY, Erdoğan, “Mihrap”, DİA, İstanbul 2005, C. 30, s. 29-30

ERTAN, Temuçin Faik, Kadrocular ve Kadro Hareketi, T.C. Kültür Bakanlığı Yayınları, Ankara, 1994

ERTAN, Temuçin Faik, Atatürk Döneminde Devletçilik-Liberalizm Tartışmaları, Phoenix, Ankara 2010

ERTAN, Temuçin Faik, "Kadro Dergisi Niçin Kapandı?”, Atatürk Dergisi Journal of Atatürk, Cilt: III, Sayı: 4

GÖRGÜN, Hilal, “Sosyalizm”, DİA, İstanbul 2009, C. 37, S. 382-388

GÜNGÖR, Mehmet, "Çağın Önünde Bir Aydın: İsmayıl Hakkı Baltacıoğlu”, Mersin Üniversitesi Eğitim Fakültesi Dergisi, Cilt 4, Sayı 1, Haziran 2008

75 Peyami Safa, Türk İkılabına Bakışlar, Ötüken, İstanbul 2017, s. 13 
GÜNDÜZ, Mustafa, 2. Meşrutiyet'in Klasik Paradigmaları, Lotus, Ankara 2007

KARAOSMANOĞLU, Yakup Kadri, Zoraki Diplomat, İletişim Yay, 2018

KARPAT, Kemal, Türk Demokrasi Tarihi, Timaş Yayınları, İstanbul 2010

KAHRAMAN, Alim, "Milli Mecmua”, DIA, İstanbul 2005, C. 30

KILIÇ, Sezen, "Cumhuriyetin İlk Yıllarındaki Gelişmeleri Basının Yorumlayışı (19231926)", Atatürk Araştırma Merkezi Dergisi, C. 24, Say1: 70, 2008, s. 149-194

MARDİN, Şerif, “Adem-i Merkeziyet”, DİA, İstanbul 1988, C.1, s. 364-367 2016

OKSAÇAN, Halit Erdem, “Kadro” Dergisi ve İktisadi Devletçilik, Agora Kitaplı̆̆ı, İstanbul

ORAL, Mustafa, Kemalist Cumhuriyet'in İnşası Bir İdeolojik Aygıt Olarak Ülkü Mecmuası, Yeni İnsan Yayınevi, İstanbul, Mayıs 2016

ÖZCAN, Azmi, “Osmanlıc1lı", DIA, İstanbul 2007, C. 33, s. 485-487

PEKER, Recep, "Ülkü Niçin Çıkıyor”, Ülkü Mecmuası, 1933, Cilt:1, Sayı:1

SAFA, Peyami, Türk İnkılabına Bakışlar, Ötüken, İstanbul 2017

TOPRAK, Zafer, “Aydınlık Dergisi [1921-1925], Marksizm ve Feminizm," Müteferrika, say1 50, Kış 2016/2

TOPRAK, Zafer, Dergiler Ansiklopediler, Gelişim, İstanbul 1984

TIMUR, Taner, Türk Devrimi ve Sonrası, İmge Kitabevi, 8. Bask1, Ankara 2018

UÇAR, Fuat, "Türk Düşüncesinde Osmanlıcılık Fikrinin Ortaya Çıkışı ve Türk Siyasal Hayatına Etkileri”, Karadeniz Sosyal Bilimler Dergisi, Haziran 2018, C. 10, s. 85-86

UÇMAN, Abdullah, "Dergâh", DİA, İstanbul 1994, C. 9, s. 172-173

UÇMAN, Abdullah, "Hayat", DİA, İstanbul 1988, C.17, s. 12-14

ÜNAL, Suzan 1923 ve 1927 Seçimleri, Dora, Bursa 2016

UZUN, Hakan, "Tek Parti Döneminde Yapılan Cumhuriyet Halk Partisi Kongreleri Temelinde Değişmez Genel Başkanlık, Kemalizm ve Milli Şef Kavramları”, Dokuz Eylül Üniversitesi Çağdaş Türkiye Tarihi Araştırmaları Dergisi, Cilt IX, Sayı 20-21, 2010 Bahar-Güz

ÜSTEL, Füsun, Türk Ocaklarl, İletişim Yay., 3. Bsk., İstanbul 2010

ÜLKEN, Hilmi Ziya, Türkiye'de Çağdaş Düşünce Tarihi, Ülken Yay., 2. Bsk, İstanbul 1979

YESEVİ, Çağla Gül, “Türk Milliyetçiliğinin Evrimi”, Sosyal ve Beşeri Bilimler Dergisi, C. 4, No:2, 2012, s. 75-85

\section{Yayımlanmamış Tezler}

ATALAY, Lemi, Atatürk Dönemi Düsünürlerinin Gözüyle Kemalizm ve Türk Inkılabl, Ankara Üniversitesi Türk İnkılap Tarihi Enstitüsü, Yayımlanmamış Yüksek Lisans Tezi, Ankara 2004

DEMİRCi, H. Aliyar, Çı̆̆ır Dergisi ve Hıfıı Oğuz Bekata, Ankara Üniversitesi, Sosyal Bilimler Enstitüsü, Kamu Yönetimi ve Siyaset Bilimi Ana Bilim Dalı, Yayımlanmamış Yüksek Lisans Tezi, Ankara 1995

METE, Ömer, Anılarda Takrir-i Sükûn Dönemi Uygulamaları (1925-1929), Ankara Üniversitesi, Türk İnkılâp Tarihi Enstitüsü, Yayımlanmamış Yüksek Lisans Tezi, Ankara 2014 
TEPEBAŞI, Ayşe, Mihrab, Şen Yuva, Çăglayan, Meşale, Çı̆̆ır Dergilerinin Değerlendirilmesi, Tahlili ve Fihristi, Gaziosman Paşa Üniversitesi, Sosyal bilimler Enstitüsü, Yayımlanmamış Yüksek Lisans Tezi, Tokat 2011

\section{İnternet Kaynakları}

TUNCER, Hüseyin, “Türk Yurdu”, TDV İslâm Ansiklopedisi, https://islamansiklopedisi.org.tr/ turk-yurdu İ.G.T. (04.12.2018). 